Civil Engineering

Volume 170 Issue CE5

Crossrail project: a deep-mined station on the Elizabeth line, London

St. John, Barker, Frost and Harris
Proceedings of the Institution of Civil Engineers Civil Engineering 170 May 2017 Issue CE5 Pages 47-56 http://dx.doi.org/10.1680/jcien. 16.00011 Paper 1600011

Received 04/04/2016 Accepted 30/09/2016

Keywords: tunnels \& tunnelling/geotechnical

engineering/project management.
.

\title{
Crossrail project: a deep-mined station on the Elizabeth line, London
}

Adrian St. John BEng, Eur Ing, FICE, CEng

Chief Engineer, Kier Infrastructure, part of BFK JV, London, UK

John Barker BSC, Eur Ing, MICE, CEng

Manager of Engineering (London Underground stations), Aecom on behalf of Crossrail, London, UK
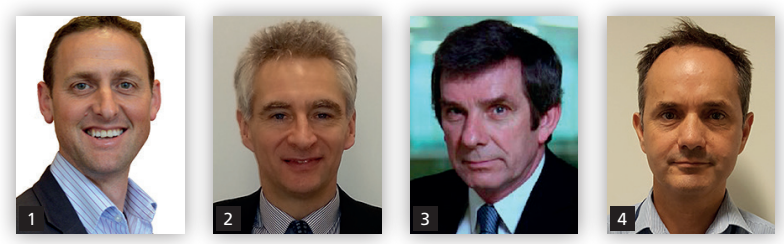

Stephen Frost BSC, Eur Ing, FICE, CEng, MCIHT C134 Lead Engineer (Civil), Arup Atkins JV, London, UK

David Harris BSC, MSC, DIC, CEng, MICE, CGeol, FGS C121 Package Manager, Mott MacDonald, Croydon, UK

This paper describes some of the key challenges and lessons learned in creating a deep-mined, sprayed concretelined station shell for London's new Elizabeth line. Tottenham Court Road station was one of five such stations on the $\mathbf{f 1 4 . 8}$ billion Crossrail project to deliver a new $118 \mathrm{~km}$ east-west railway across the UK capital by 2019 . Creation of two $240 \mathrm{~m}$ long platform tunnels in a dense, urban environment required the development of unique design and construction solutions, including ground improvement and safeguarding measures to mitigate ground movement. Strong collaboration and effective technical and construction coordination across the many asset interfaces were key factors in achieving a successful outcome.

\section{Introduction}

The $£ 14 \cdot 8$ billion Crossrail project to deliver the new $118 \mathrm{~km}$ Elizabeth line east-west railway across London, UK includes the construction of eight new deep underground stations in the central London section. Delivering a new world-class railway, which will increase London's rail capacity by approximately $10 \%$, has presented numerous challenges.

The new stations will provide bright, spacious underground spaces to facilitate high volumes of passenger movements across central London. All stations are required to make provision for trains up to $240 \mathrm{~m}$ long, thus being compatible with the longest trains in use on the UK conventional rail network. However, it was not practical to acquire work sites of this length in central London and this led to a typical station configuration comprising a shaft at each end of the station with platforms and connecting passageways constructed by mining techniques. The shafts provided worksites and accommodated ticket halls, lifts and escalators, ventilation and station plant. Typically, an over-site development was to be incorporated above the ticket halls.

Following extensive passenger modelling studies, a minimum useable platform width of $4.5 \mathrm{~m}$ was established. Platform screen doors were to be provided and these, together with EU technical specifications for interoperability and a $25 \mathrm{kV}$ overhead line equipment traction system, led to determination of a minimum internal platform tunnel diameter of $10.6 \mathrm{~m}$. The only practical technique for achieving this sort of dimension on five of the eight deep stations was considered to be mining using sprayed concrete linings (Figure 1). The $6 \cdot 2 \mathrm{~m}$ inner diameter running tunnels in this location were constructed conventionally using tunnel-boring machines.

The tunnelling strategy proposed long tunnel-boring machine drives from Limmo in the east and from Westbourne Park in the



Figure 1. Cross-section of deep-mined platform tunnel illustrating complexity of design contract scope and interfaces

west, both terminating at Farringdon, thus permitting spoil removal by way of barge and rail, respectively.

The timing of the tunnel drives was crucial. Initial studies focused on a sequence whereby the platform tunnels would be constructed first using a temporary logistics access shaft located at one of the ticket hall sites. The tunnel-boring machines would then be pulled through a completed platform tunnel. The disadvantage of this approach was that the station shaft permanent works construction could not progress effectively until the tunnel-boring machine drives were complete, because the shaft could not be safely constructed while also providing temporary tunnelling logistics. 
Crossrail project: a deep-mined station

on the Elizabeth line, London

St. John, Barker, Frost and Harris
In the case of Tottenham Court Road, which was towards the end of the western tunnelling drive, this created a long delay to the station programme, but was considered, on balance, to be the optimal solution in the context of undertaker Crossrail Limited's wider procurement and programme strategy. This key disadvantage was only finally resolved in 2011 when the contracts for both bored (C300) and mined (C410) tunnels were won by the same contractor - BFK, a joint venture of BAM, Ferrovial and Kier. The contractor proposed an alternative early tunnelling sequence, whereby the platform tunnels would be constructed after the passage of the tunnel-boring machines using an enlargement technique. This reduced the programme by 7 months, produced savings of $£ 80$ million, reduced settlement by $30 \%$ and reduced the number of lorry movements by 50000 (St. John et al., 2015b).

It was still necessary to provide access to the tunnel zones before the tunnel-boring machine arrival to undertake early sprayed concrete lining works. Adopting a 'bottom-up sequence' for the Tottehham Court Road western ticket hall meant that it was possible to complete the station foundations, excavate the shaft and construct the base slab well before the arrival of the tunnel-boring machine. Construction of the station shaft foundations was awarded as a separate contract and the excavation, including the propping design, was included in BFK's scope to reduce construction interfaces. On completion of the tunnelling, the shaft was to be handed over to a station fit-out contractor, who would remove the props, construct the station internal structure and complete the design and installation of the mechanical, electrical and plumbing elements and the architectural finishes.

This paper focuses on the construction of the Tottenham Court Road station shafts and tunnels. The alignment at this location runs parallel to London Underground's Central line and crosses the Northern line tunnels with minimal clearance. A total of 120 buildings including one grade I and 25 grade II listed structures were within a predicted settlement zone of $1 \mathrm{~mm}$ and there were a large number of other sensitive utilities in the area. Extensive measures were taken to protect these surrounding structures, and these are described more fully in Section 5.

\section{Station configuration}

Tottenham Court Road station is situated at the east end of Oxford Street and will provide access to shopping, office and residential space. The station is situated in the south-west quadrant of the junction formed by the intersection of Oxford Street and Charing Cross Road (Figures 2, 3 and 4).

The layout of the station was dictated by the horizontal and vertical tunnel alignment, the need to avoid piled foundations to the east of Tottenham Court Road and, accordingly, the limits of deviation defined by the Crossrail Act (Li et al., 2014). These prescribed limits in plan and profile forced the eastbound platform tunnel to follow a curved alignment. The eastern end of the Crossrail station was integrated with London Underground's major upgrade of the existing underground station, which was also authorised as part of the Crossrail Act and was under construction at the same time as the Crossrail project.

It was agreed between London Underground and Crossrail that it was not practical to have two contractors working in close proximity, so the construction of the eastern shaft of the Crossrail station, known as Goslett Yard box, was entrusted to London

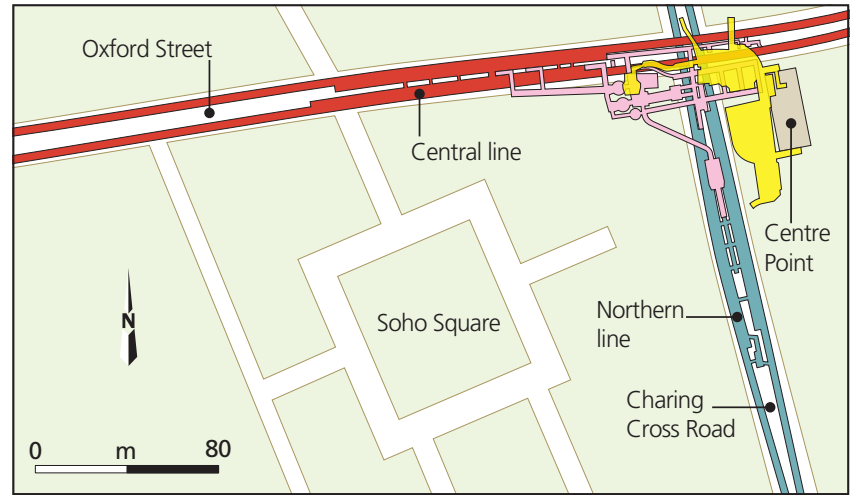

Figure 2. Tottenham Court Road station plan view before Crossrail - Westbourne Park is to the left, Farringdon is to the right



Figure 3. Tottenham Court Road station plan view after Crossrail

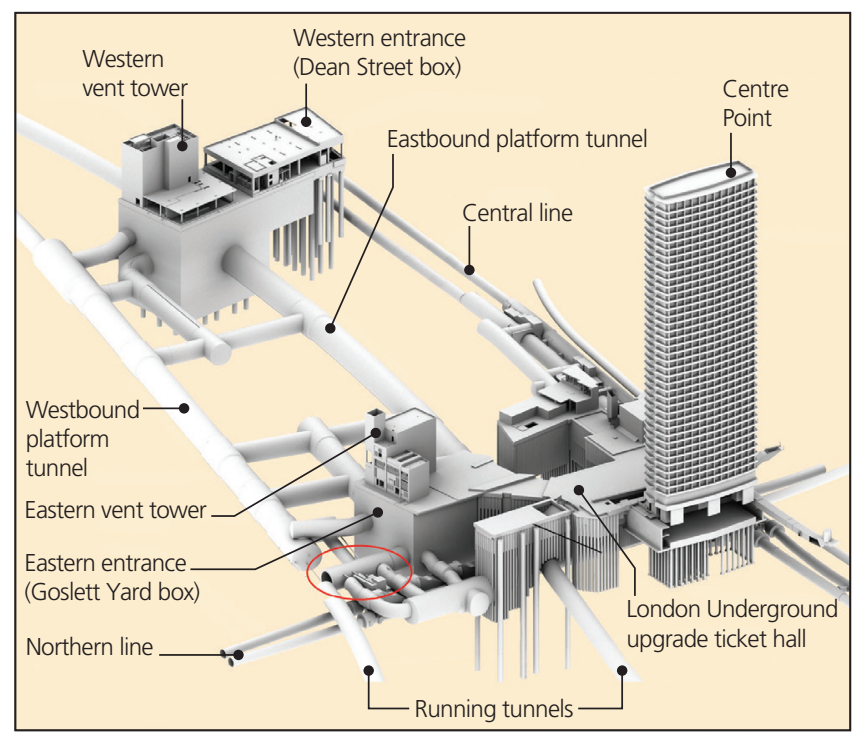

Figure 4. Three-dimensional view of Tottenham Court Road station - the complex arrangement around tunnel AP8 is circled in the foreground 
Civil Engineering

Volume 170 Issue CE5
Crossrail project: a deep-mined station

on the Elizabeth line, London

St. John, Barker, Frost and Harris
Underground and was delivered by its station upgrade contractor. The new London Underground ticket hall serves both Crossrail and London Underground passengers.

The station provides a major interchange between Crossrail and the Northern line. However, the close spacing of the Northern line platform tunnels meant that London Underground could not include escalators between them, which resulted in a stepped interchange between London Underground and Crossrail. The design therefore sought to minimise the height of the interchange, resulting in minimal clearances as the Crossrail running tunnels passed over the Northern line, which remained live. The eastbound tunnel had a nominal clearance of $600 \mathrm{~mm}$ while it threaded through the triangular opening formed by the south face of the new London Underground ticket hall and the underside of the London Underground and Crossrail escalators (BBC2, 2016) (Figure 5).

The western ticket hall located at Dean Street contains a single escalator bank running from street to platform level. The site is bisected by Fareham Street, which was closed during construction, and was to be relocated further north in order to provide viable development plots to both north and south. The ticket hall is located in the north block and the station entrance was moved into Dean Street, thus preserving Oxford Street as a retail frontage.

Third-party assets constrained the design of the foundations. London Underground's Central and Northern lines dictated the proximity of foundations, while deep subsurface BT telecommunications tunnels and other utility structures dictated both footprints and construction techniques. Fareham Street had major BT infrastructure at depth, which was diverted around the southern perimeter of the site as part of the advanced works.

Both station boxes were formed by diaphragm wall panels. The eastern Goslett Yard box was connected to the neighbouring London Underground upgrade ticket hall using secant piling and was excavated in a top-down sequence. The western ticket hall box was constructed using bottom-up techniques with temporary propping to expedite excavation of the box, allowing its use as a construction site and access shaft to service the sprayed concrete lining tunnelling works.

The approach supported the revised tunnel drive programme strategy known as 'tunnel-boring machine first', which was

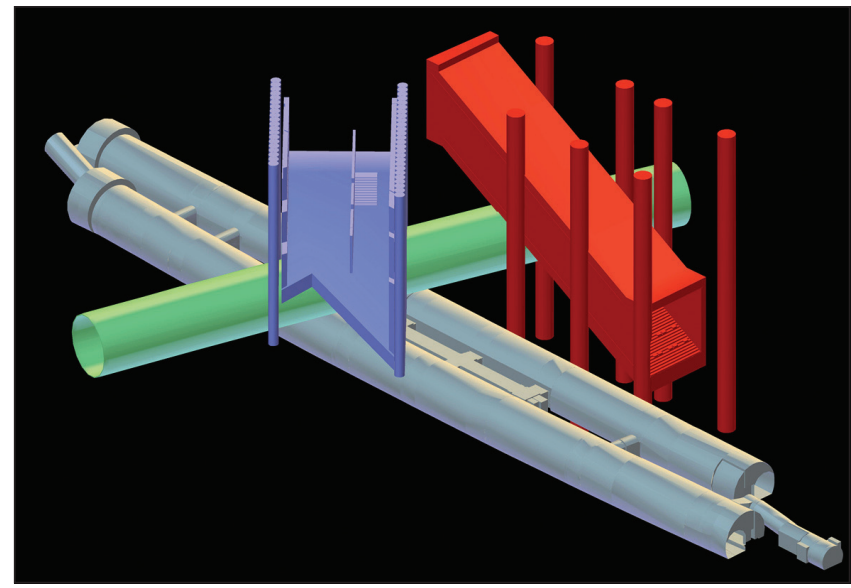

Figure 5. Threading the eye of the needle - the new eastbound Crossrail running tunnel (green) passed under and between existing critical assets, and only $600 \mathrm{~mm}$ above the live London Underground Northern line platforms introduced as part of BFK's bid-winning solution (St. John et al., $2015 b)$. In addition to the western ticket hall acting as a sprayed concrete lining access shaft, the accelerated excavation of the western ticket hall also ensured that the lowest raft construction was in place prior to the transit of the eastbound tunnel-boring machine (Figure 6).

Both subsurface box structures have ventilation towers rising from them, with the western ticket hall rising six storeys and the Goslett Yard box five storeys. These provide stability to over-site development structures built over the station structures. The western over-site development structure is seven-storey residential while the eastern over-site development structure is a nine-storey theatre and office.

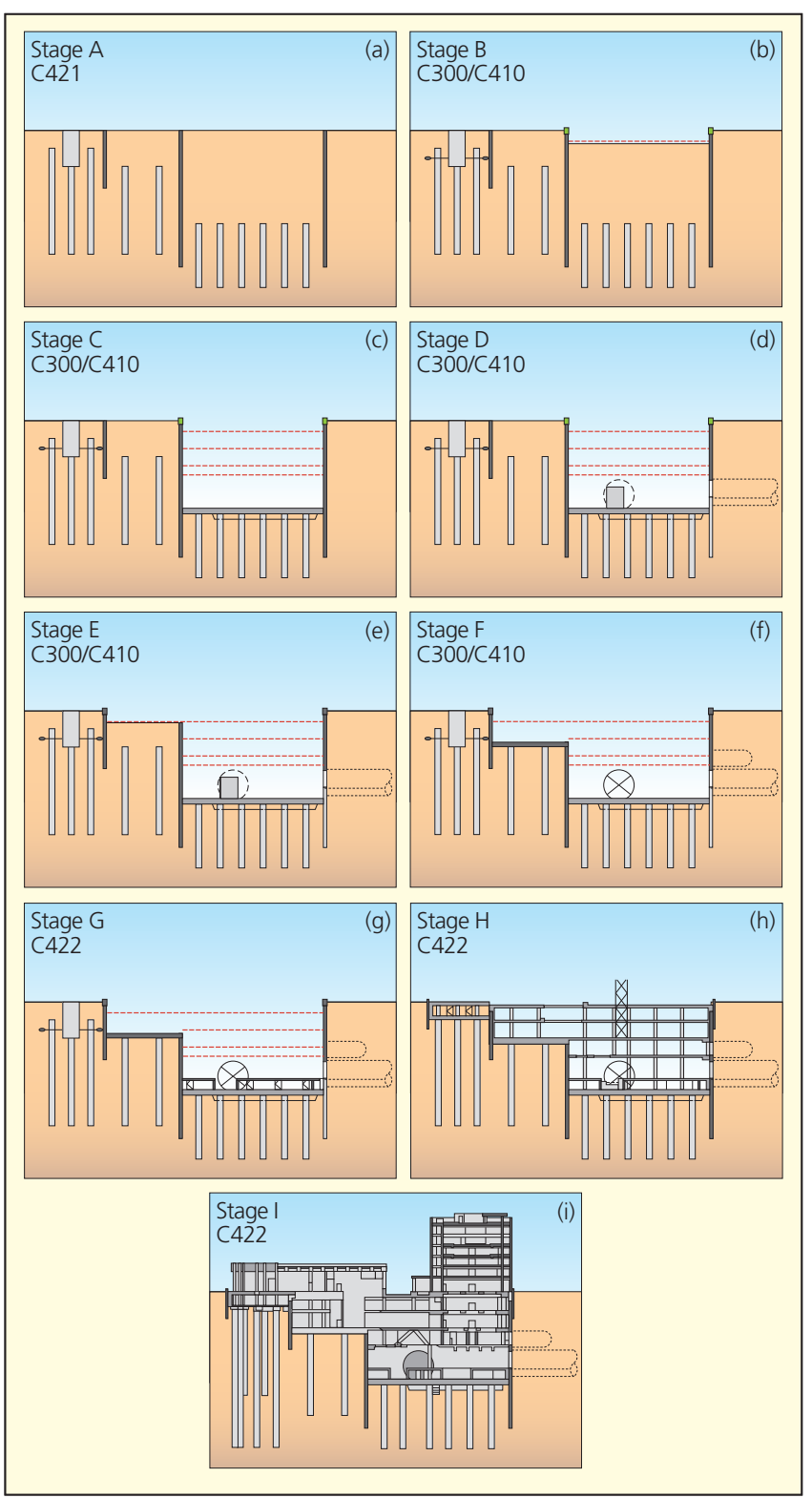

Figure 6. Construction sequence for western ticket hall excavation and propping (a) diaphragm walling; (b), (c), (d) excavation, temporary propping and base slab (south box); (e), (f), (g) excavation, temporary propping and base slab (north box); (f), (h), (i) bottom-up construction of permanent works 
Tottenham Court Road station is also space-proofed for a future connection from below between the Elizabeth Line and the proposed north-south Crossrail Line 2, which is planned to pass beneath the Elizabeth Line. The passenger capacities of the central concourse passages connecting to the two boxes and the escalators have allowed for the future passenger forecast from Crossrail Line 2. When this connection is made, there will be a continuous central concourse between the two box structures. beneath Soho Square.

Ground conditions were typical of London, with made ground over river terrace deposits over London Clay over the Lambeth Group (Figure 7). The majority of the two boxes and the whole of the tunnels are in the London Clay.

Design and construction for the civil engineering works was procured through a number of separate contracts, as shown in Table 1. Figure 8 shows the design interfaces and Figure 9 the overall construction sequence and durations.

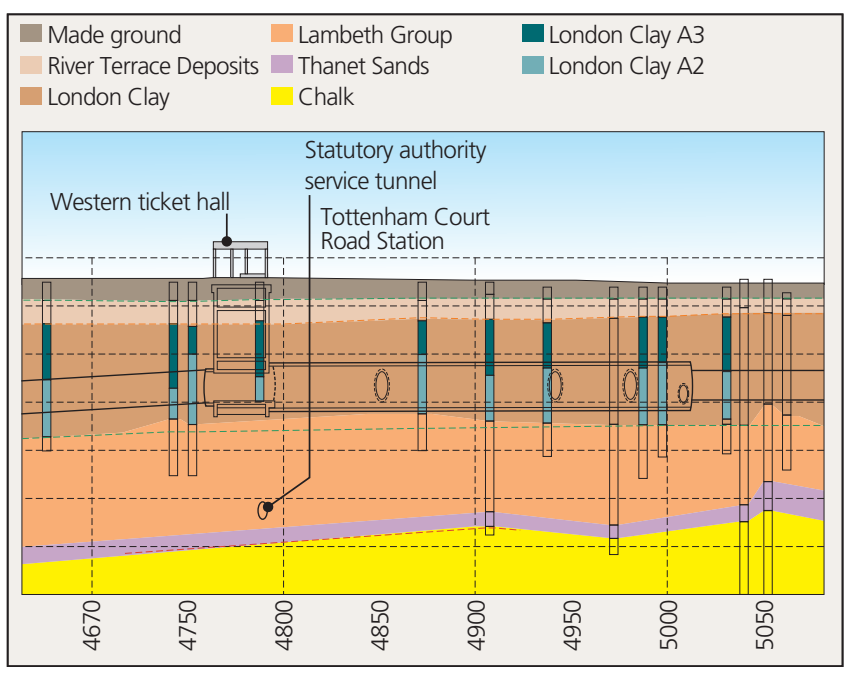

Figure 7. Geological long-section of Tottenham Court Road station

Table 1. Tottenham Court Road design and construction contracts

\begin{tabular}{|c|c|c|c|}
\hline Scope & $\begin{array}{l}\text { Design } \\
\text { contract }\end{array}$ & Designer & Scope \\
\hline Main station design & C134 & Arup-Atkins joint venture & $\begin{array}{l}\text { Overall station configuration, civil engineering design for } \\
\text { western ticket hall to RIBA F and MEP/architecture to RIBA E }\end{array}$ \\
\hline Sprayed concrete lining tunnels & C121 & Mott MacDonald & All permanent and temporary sprayed concrete lining \\
\hline $\begin{array}{l}\text { Running tunnels and asset } \\
\text { protection }\end{array}$ & C122 & Arup-Atkins joint venture & $\begin{array}{l}\text { Including assessment of all infrastructure/buildings impacted } \\
\text { by ground movement }\end{array}$ \\
\hline Scope & $\begin{array}{l}\text { Construction } \\
\text { contract }\end{array}$ & Contractor & Scope \\
\hline Demolition and utilities & C208 & McGee Group & \\
\hline Station foundations & C421 & $\begin{array}{l}\text { Balfour Beatty-Morgan- } \\
\text { Vinci joint venture }\end{array}$ & $\begin{array}{l}\text { Including diaphragm walls and bored piles at western ticket } \\
\text { hall }\end{array}$ \\
\hline $\begin{array}{l}\text { Western running tunnels and } \\
\text { station caverns }\end{array}$ & C $300 / C 410$ & $\begin{array}{l}\text { BAM-Ferrovial-Kier joint } \\
\text { venture }\end{array}$ & $\begin{array}{l}\text { Including station caverns at Bond Street and Tottenham Court } \\
\text { Road, including Tottenham Court Road western ticket hall } \\
\text { shaft excavation }\end{array}$ \\
\hline Main station fit-out & $\mathrm{C} 422$ & Laing O'Rourke & \\
\hline $\begin{array}{l}\text { Tottenham Court Road London } \\
\text { Underground station upgrade }\end{array}$ & & $\begin{array}{l}\text { Taylor Woodrow-BAM } \\
\text { Nuttall joint venture }\end{array}$ & Including Goslett Yard box structure to ground level \\
\hline
\end{tabular}

\section{Western ticket hall construction}

The foundations and excavation of the western ticket hall were the first stage of construction. The project team were presented with three particularly significant challenges.

First, the footprint of the permanent works at the western ticket hall extended to over $90 \%$ of the worksite, requiring careful sequencing, logistics and craneage solutions to be deployed for the excavation of the ticket hall and beyond. The site was in the heart of London, fronting on to Oxford Street, with extremely restricted access (Figure 10).

The site was also the main worksite to support the sprayed concrete lining tunnelling works, meaning that the permanent works for the ticket hall could not be progressed while tunnelling continued. This was a considerable constraint, and contrasted with Liverpool Street station where a temporary shaft, dedicated to tunnelling logistics, was constructed in the heart of the station at Finsbury Circus. Such an arrangement was not permissible within Soho Square.

Second, there was significant interface with the tunnelboring machine drives, in particular the method for transiting the tunnel-boring machines across the station voids. Third, there was a major interface between the sprayed concrete lining and tunnel-boring machine works, particularly the pre- and posttunnel-boring machine scope of works, necessitating complex logistics to maintain continuity of sprayed concrete lining work. This was exacerbated by restricted access by way of the London

With the permanent works taking up such a large element of the worksite, the contractor opted to install a large gantry crane $(25 \mathrm{t}$ capacity, $25 \mathrm{~m}$ span) to service the works, and split the excavation into two phases. Phase 1 entailed the excavation and temporary propping of the main (southern) part of the box down to level -5 , as illustrated at stage D on Figure 6. This left the northern section of the worksite available for spoil handling and disposal, and space for a temporary shotcrete batching plant to support the sprayed concrete lining works.

Phase 2 then involved the excavation and propping of the northern portion of the ticket hall, a two-level basement, as Underground works at Goslett Yard box. 
Civil Engineering

Volume 170 Issue CE5
Crossrail project: a deep-mined station

on the Elizabeth line, London

St. John, Barker, Frost and Harris

\begin{tabular}{|c|c|c|c|}
\hline Discipline & $\begin{array}{l}\text { Station } \\
\text { package }\end{array}$ & $\begin{array}{c}\text { Platform and } \\
\text { passenger } \\
\text { tunnels } \\
\text { package }\end{array}$ & $\begin{array}{c}\text { Linewide } \\
\text { (running tunnels) } \\
\text { package }\end{array}$ \\
\hline Premises & \multicolumn{2}{|c|}{ C134 C100 } & C122/C100 \\
\hline \multirow{5}{*}{ Civil/structural } & C134 & \multirow{2}{*}{ C121 } & \\
\hline & C208/C241 & & C122 \\
\hline & \multicolumn{2}{|c|}{ C122 (settlement mitigation) } & \\
\hline & $\begin{array}{l}\text { London } \\
\text { Underground } \\
\text { (TWBN) } \\
\text { GYB-Civil }\end{array}$ & C121 & C122 \\
\hline & $\begin{array}{l}\text { London } \\
\text { Underground } \\
\text { upgrade } \\
\text { works }\end{array}$ & $\begin{array}{l}\text { London } \\
\text { Underground } \\
\text { upgrade } \\
\text { works }\end{array}$ & C122 \\
\hline Mechanical/electrical & \multicolumn{2}{|c|}{ C134 } & C124 \\
\hline Fire & \multicolumn{2}{|c|}{ C134 } & C122 \\
\hline Power & \multicolumn{2}{|c|}{ C164 } & C124 \\
\hline Communications & \multicolumn{2}{|c|}{ C134/C170 } & C170 \\
\hline Ventilation & \multicolumn{2}{|c|}{ C134/C124 } & C124 \\
\hline $\begin{array}{l}\text { Over-site developments } \\
\text { east London Under- } \\
\text { ground ticket hall and } \\
\text { Goslett Yard box }\end{array}$ & \multicolumn{2}{|c|}{$\begin{array}{l}\text { Derwent London } \\
\text { (AHMM) }\end{array}$} & \\
\hline $\begin{array}{l}\text { Over-site developments } \\
\text { site } C \text { and } D\end{array}$ & \multicolumn{2}{|c|}{ C134 } & \\
\hline \multicolumn{4}{|c|}{$\begin{array}{l}\text { C134: Tottenham Court Road station design; C100: Architectural } \\
\text { components design; C121: Sprayed concrete linings design; C122: Bored } \\
\text { tunnels design - alignment and track; C124: Railway systems and tunnel M } \\
\text { and E services; C164: Bulk power distribution and HV system; C170: } \\
\text { Communications and control systems design; C208: Tottenham Court Road } \\
\text { demolition; C241: Utility diversions }\end{array}$} \\
\hline
\end{tabular}

Figure 8. Design interface table

shown at stage $\mathrm{F}$ on Figure 6. The deployment of a state-of-theart, reliable, high-capacity batching plant was considered to be a critical success factor, since it also served the Crossrail Bond Street station sprayed concrete lining works (Figure 11).

The value engineering re-design of the temporary propping using the observational method (Nicholson et al., 1999) and the successful excavation of the western ticket hall have already been documented in some detail (Yeow et al., 2014). This acclaimed piece of engineering delivered savings of around $£ 5$ million and 6 weeks on the programme. It deleted the lowest level of propping across both the southern and northern portions of the box, which avoided the need for fabrication, installation and removal of large steel sections in a very confined working area with consequential safety and sustainability benefits (de Silva and Paris, 2015).

The permanent works design proved to be versatile and resilient enough to permit such a key change in approach. A clever temporary dowelling solution through the diaphragm wall panel joints and careful sequencing of the works also avoided any additional temporary framing around the tunnel openings in the box. This provided the contractor's tunnelling team with early access to start sprayed concrete lining tunnelling well ahead of the arrival of the tunnel-boring machines. The western ticket hall formed the principal access for the logistics to support the majority of the sprayed concrete lining tunnelling works.

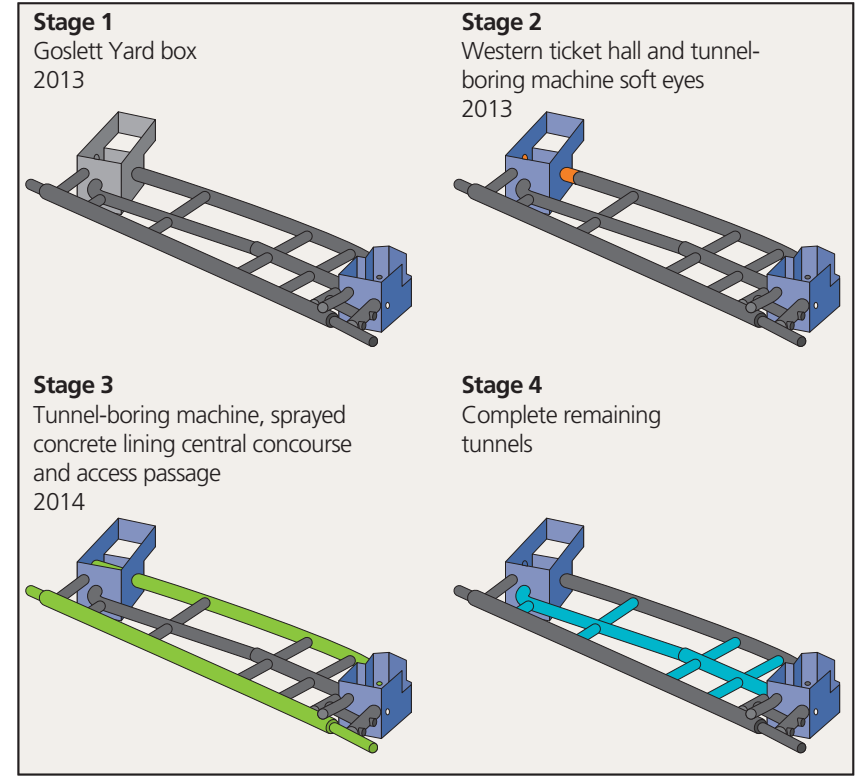

Figure 9. Overall construction sequence and durations: stage 1 Goslett Yard box; stage 2 Tottenham Court Road western ticket hall excavation and sprayed concrete lining soft eyes; stage 3 tunnel-boring machine drives and sprayed concrete lining works; stage 4 completion of remaining sprayed concrete lining tunnels

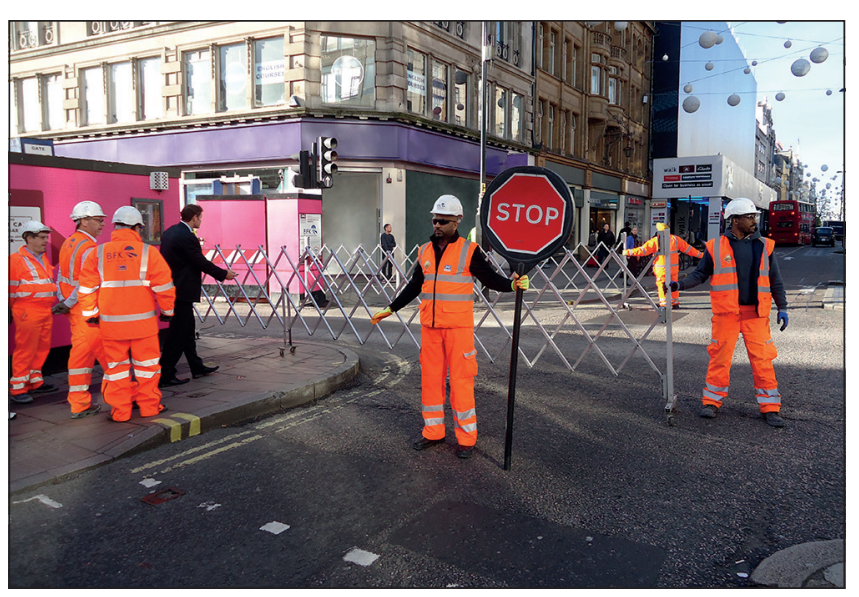

Figure 10. Exemplary pedestrian control on Oxford Street at the site entrance

\section{Sprayed concrete lining tunnelling}

\subsection{Design}

The platform, concourse and ventilation tunnels were constructed using sprayed concrete linings. This process involved excavating tunnels in $1 \mathrm{~m}$ advances, which were subdivided depending on the size of the tunnel diameter into top headings and inverts, or into top headings, benches and inverts (Figure 12). The system differed from the new Austrian tunnelling method techniques in that the sprayed concrete lining design philosophy was to deliver a fully engineered and assured design prior to construction. The only changes permitted during the works were to deploy additional 'temporary measures' to provide additional excavation support. 
Crossrail project: a deep-mined station

on the Elizabeth line, London

St. John, Barker, Frost and Harris

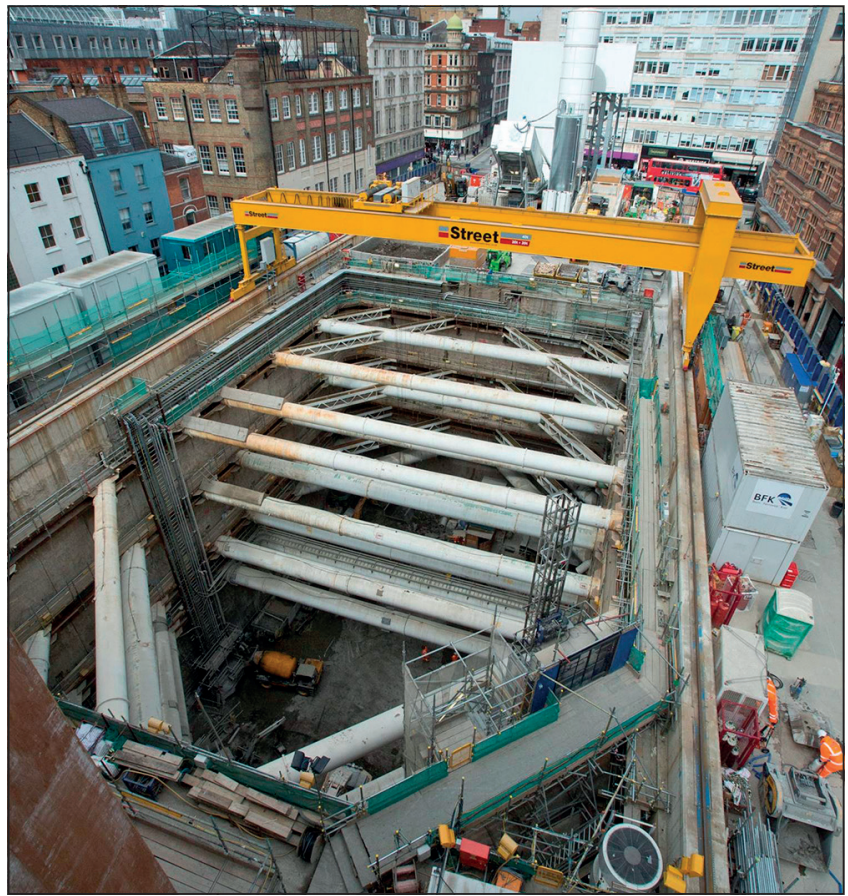

Figure 11. Tottenham Court Road western ticket hall showing gantry crane, temporary propping scheme, shotcrete batching plant with Oxford Street immediately beyond - excavation took around 9 months from January to October 2012

The works were monitored and strictly controlled using a daily shift review group attended by the client, contractor and designer, and a 'required excavation support sheet'. The contractor employed Donaldson Associates as its specialist sprayed concrete lining designer, responsible for a technical due diligence review of Mott MacDonald's lining design and for design of temporary measures (St. John et al., 2015a). This ensured safe and effective integration of the permanent and temporary works designs.

The principles of sprayed concrete lining design are described in detail elsewhere (Pickett, 2015; Gakis et al., 2015; Su and Thomas, 2015), but broadly comprised the following (Figure 13)

- $75 \mathrm{~mm}$ thick steel-fibre-reinforced concrete initial lining

- $\quad 175-300 \mathrm{~mm}$ thick steel-fibre-reinforced concrete primary lining

- $40 \mathrm{~mm}$ thick smoothing layer (free of steel fibres)

- sprayed waterproofing membrane

- 200-250 mm thick steel-fibre-reinforced concrete sprayed concrete secondary lining

- $50 \mathrm{~mm}$ thick sprayed concrete fire protection layer dosed with polypropylene fibres.

A two-pass approach to tunnel junctions was adopted. A flared primary lining in the 'parent' (larger) tunnel was augmented by a bar-reinforced primary lining thickening section, which then permitted safe breakout of the 'child' (smaller) tunnel.

\subsection{Arrangement}

Tottenham Court Road sprayed concrete lining tunnels consisted of an east and westbound platform tunnel, central concourse tunnels from the western ticket hall and Goslett Yard box station boxes

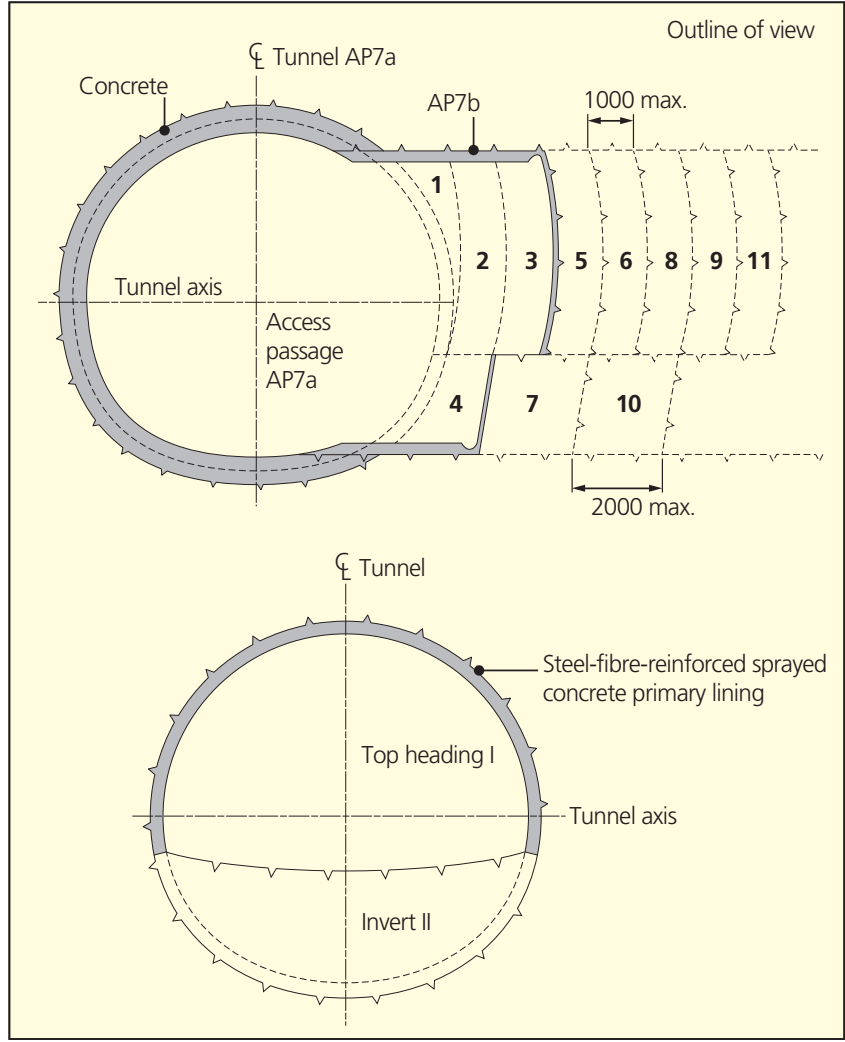

Figure 12. Face subdivision diagram in sprayed concrete lining. Each numbered stage represents a sequential phase of excavation and spraying of the sprayed concrete primary lining

connected by a temporary access tunnel, a series of connecting tunnels into the existing London Underground station, ventilation tunnels at either end of the station and three service tunnels (see Figures 3 and 4).

The two platform tunnels were $10.6 \mathrm{~m}$ dia. and typically consisted of an overall lining thickness of $600 \mathrm{~mm}$, locally thickened at junctions. Use of sprayed secondary linings meant the slight curvature of the eastbound platform tunnel did not present construction difficulties compared with a conventional cast in situ secondary lining.

Both platform tunnels were enlarged after transit of the tunnelboring machines through the station (see Figures 14 and 15), utilising the segmental tunnel as a pilot tunnel (St. John et al., $2015 b$ ), and using a top heading and invert excavation sequence. Removal of the temporary tunnel segments in the platform tunnels was straightforward and undertaken relatively quickly (St. John et al., 2015b).

The central concourse tunnel ( $\mathrm{CH} 1$, see Figure 3) was $8.0 \mathrm{~m}$ dia. and exited from the southern edge of the western ticket hall, thus requiring a sharp $90^{\circ}$ bend on plan to align with the platform tunnels. The larger $9.6 \mathrm{~m}$ dia. concourse tunnel $(\mathrm{CH} 3)$ from the Goslett Yard box in the east provided access to the platform tunnels by way of two sets of cross-passages. Connections with London Underground station upgrade works were achieved by way of tunnel AP8 and three link tunnels at the east end of the site (see Figure 4). 
Civil Engineering

Volume 170 Issue CE5
Crossrail project: a deep-mined station

on the Elizabeth line, London

St. John, Barker, Frost and Harris

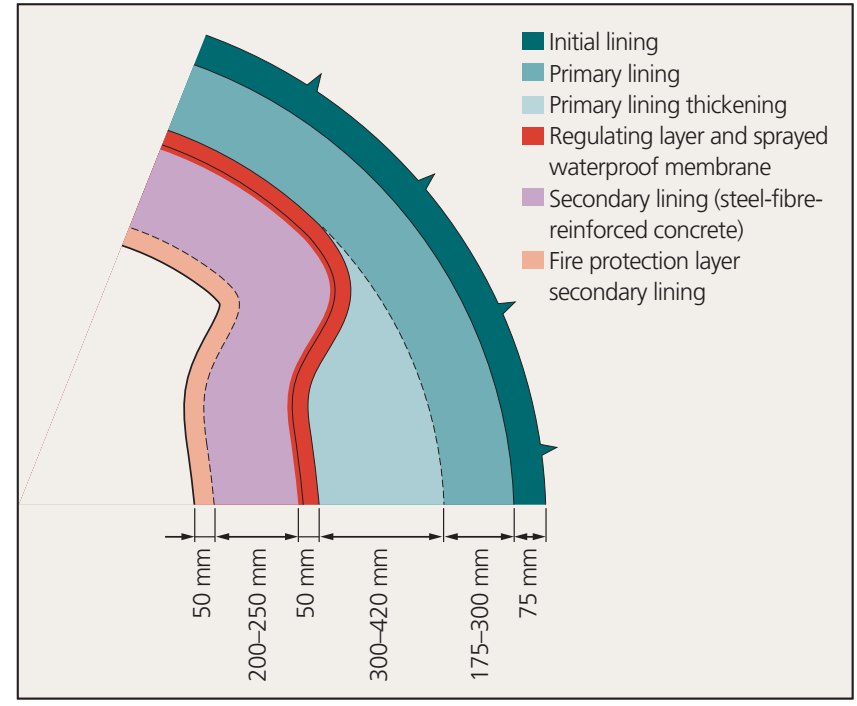

Figure 13. Composition of sprayed concrete lining - the thickened areas were restricted to the tunnel junction areas only

To meet London Underground connection configuration, the connection between AP8 and the London Underground tunnels (circled in red in Figure 4) presented several complex design challenges, including

- multiple adjacent complex tunnel junctions, with minimal clearances between them

- an existing (backfilled) temporary London Underground tunnel which overlapped with new Crossrail tunnel AP8

a the permanent headwall of tunnel AP8 touched the extrados of the new westbound Crossrail running tunnel.

Other design challenges included the station ventilation tunnels VEW and VWW. The westbound platform tunnel did not pass directly through the station boxes, so a single $6.5 \mathrm{~m}$ dia. ventilation tunnel was required at each end of the platform. The westerly ventilation tunnel VWW was on a $17^{\circ}$ incline and, somewhat unusually, was required to be mined upwards due to access restrictions at the western ticket hall. Owing to special constraints, the easterly ventilation tunnel VEW was positioned over the platform tunnel, connecting to it by means of a short vertical shaft $5 \mathrm{~m}$ in diameter (see Figure 16).

\subsection{Construction}

The 'tunnel-boring machine first' strategy required two different approaches for the two tunnel-boring machines: the westbound tunnel-boring machine required the construction of a temporary 'wrap-around' chamber at AP1 across the line of the westbound tunnel-boring machine drive. This was backfilled with low-strength foam concrete immediately prior to the arrival of the tunnel-boring machine (see Figure 17).

The eastbound tunnel-boring machine drive presented a rather greater challenge as it passed through the western ticket hall. This posed questions such as, should the tunnel-boring machine transit through fresh air or through a block of temporary foam concrete? And how much, if any, sprayed concrete lining tunnelling should be carried out prior to the arrival of the eastbound tunnel-

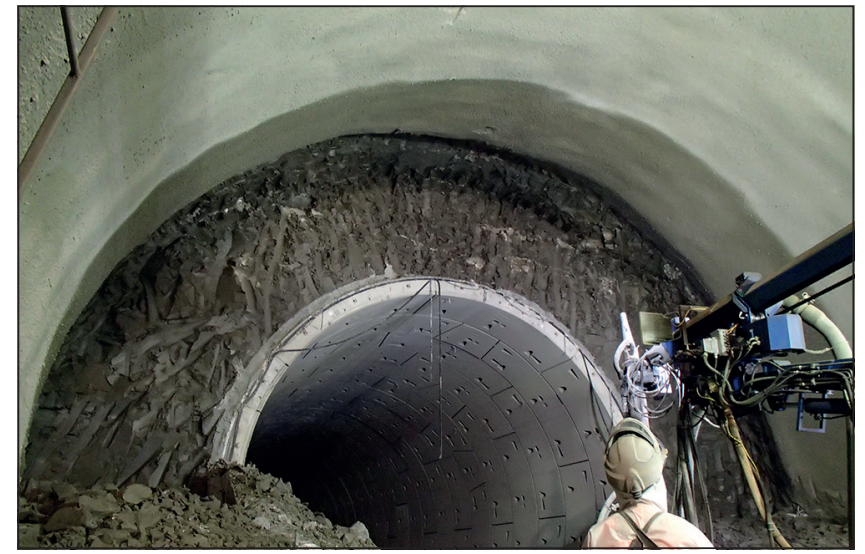

Figure 14. Sprayed concrete lining platform tunnel enlargement from a tunnel-boring machine pilot - top heading

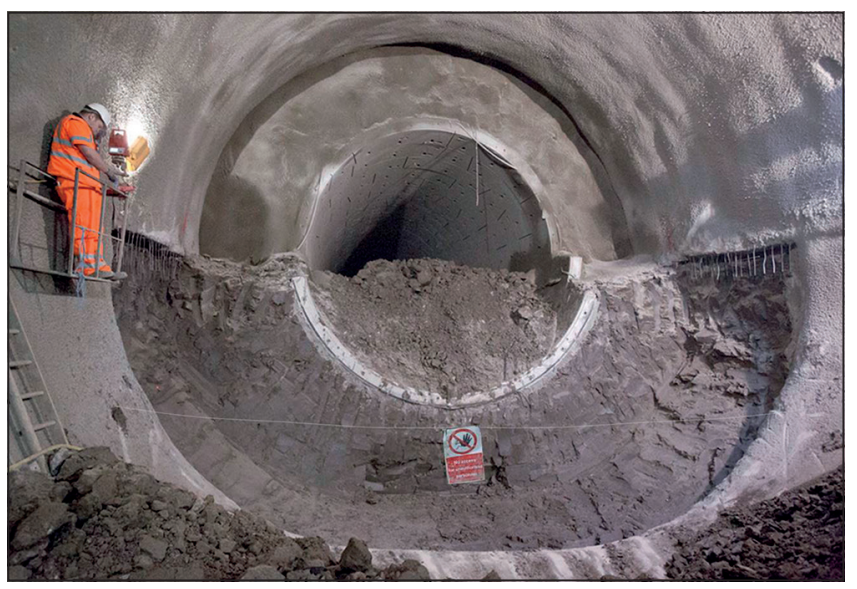

Figure 15. Sprayed concrete lining platform tunnel enlargement from a tunnel-boring machine pilot - invert

boring machine? These were key strategic decisions for the team, considering the comparative cost, programme, health, safety and risk implications of the various options.

The contractor's approach was to prioritise tunnel-boring machine progress, selecting a method which allowed the most rapid, safe and cost-effective method of enabling the tunnel-boring machine to continue on its path towards Farringdon. As a result, a large block of temporary foam concrete was constructed across the western ticket hall shaft, through which the tunnel-boring machine tunnelled, leaving in its place a series of complete temporary rings grouted into position. This was facilitated by first stitch-drilling and removing blocks of diaphragm wall and replacing them with a thin shotcrete shell (a 'soft eye') prior to the pouring of the foam concrete block.

A portion of the foam concrete block, and the associated precast tunnel rings, was subsequently cut out to enable a temporary crossconveyor belt to be installed. The cross-conveyor enabled sprayed concrete lining tunnelling spoil to be loaded onto the tunnel-boring machine conveyor belt, thus significantly reducing the number of lorry movements around Oxford Street and Soho. This provided a safe, cost-effective and sustainable means of disposing of tunnelling 
Civil Engineering

Volume 170 Issue CE5
Crossrail project: a deep-mined station

on the Elizabeth line, London

St. John, Barker, Frost and Harris

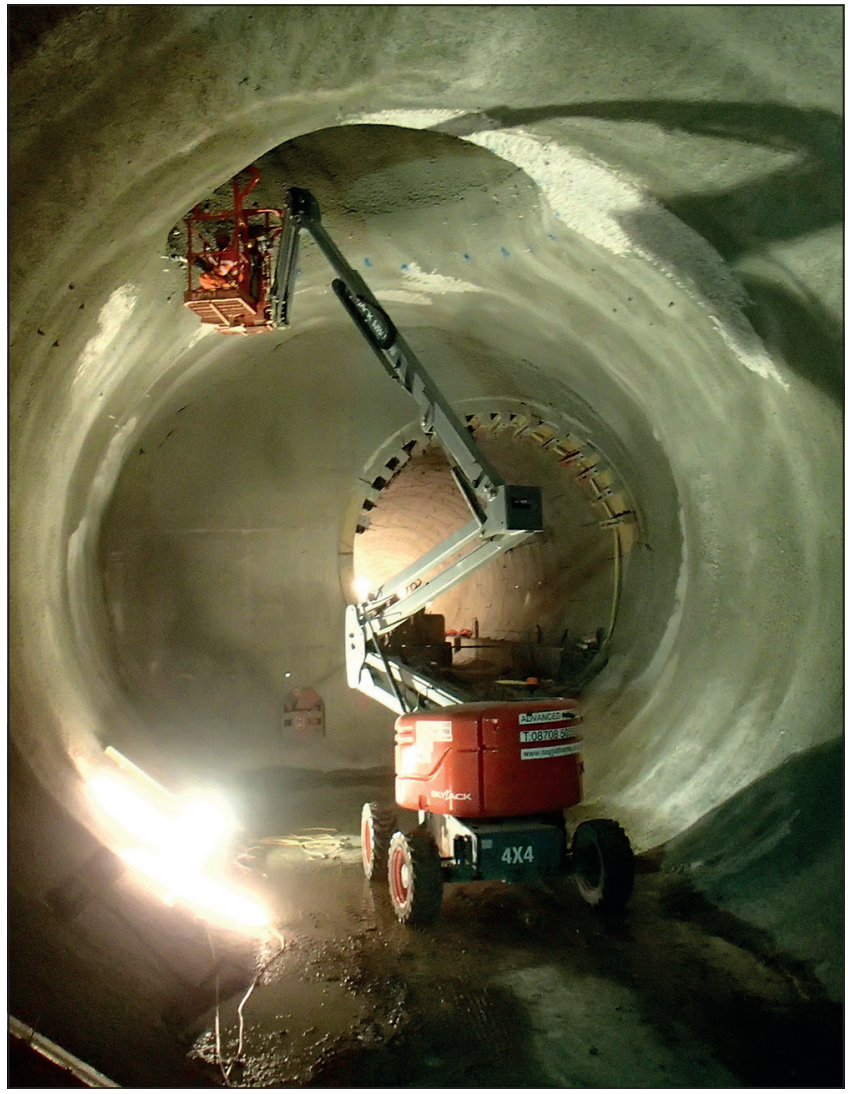

Figure 16. Ventilation tunnel VEW shaft connection into the crown of the platform tunnel

spoil by way of the purpose-built railhead at the Crossrail BFK western running tunnels worksite at Westbourne Park

The need to maintain through-access to support the tunnel-boring machine drives effectively precluded the construction of many of the sprayed concrete lining tunnels at Tottenham Court Road until the completion of the tunnel-boring machine drives at Farringdon (see Figure 9). Furthermore, the programme for constructing the sprayed concrete lining tunnels at the eastern end of the station was governed by the progress of the London Underground contractor at the Goslett Yard box. These had the potential to severely delay the sprayed concrete lining works and/or cause a hiatus in the sprayed concrete lining works.

Such a stoppage could have resulted in significant costs and disruption in terms of demobilisation and remobilisation of resources, and could have critically affected the ability to source, up-skill and maintain a skilled workforce, particularly within the over-heated labour market for specialist sprayed concrete lining personnel.

The project team recognised two key initiatives which de-risked the programme and enabled early construction of large areas of the station. First, the construction of temporary sprayed concrete lining tunnel CL1 provided the team with access to construct the easternmost sprayed concrete lining tunnels (see Figure 18). This link was augmented by a temporary sprayed concrete lining connecting tunnel between $\mathrm{CH} 3$ and $\mathrm{AP} 7 \mathrm{a}$, opening up yet more

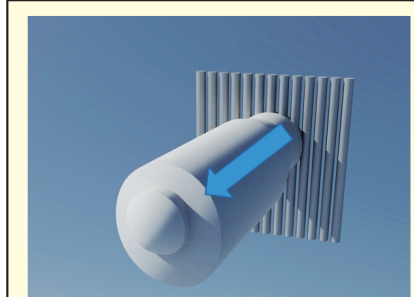

(a)

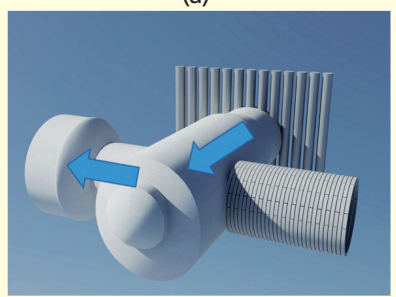

(c)

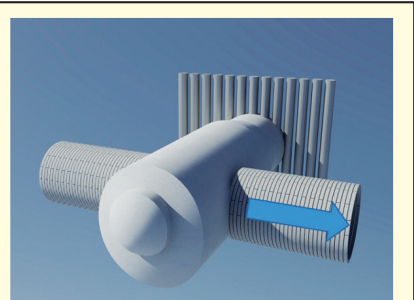

(b)

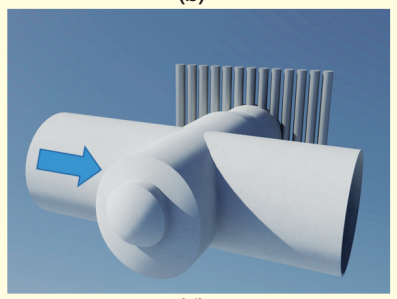

(d)
Figure 17. Complex sprayed concrete lining sequencing was required to form the permanent works using the 'tunnel-boring machine first' initiative: (a) sprayed concrete lining pilot tunnel and wrap-around chamber; (b) tunnel-boring machine transit through wrap-around; (c) initial enlargement of tunnel-boring machine pilot tunnel using sprayed concrete lining; and (d) final back-excavation to complete sprayed concrete lining enlargement works

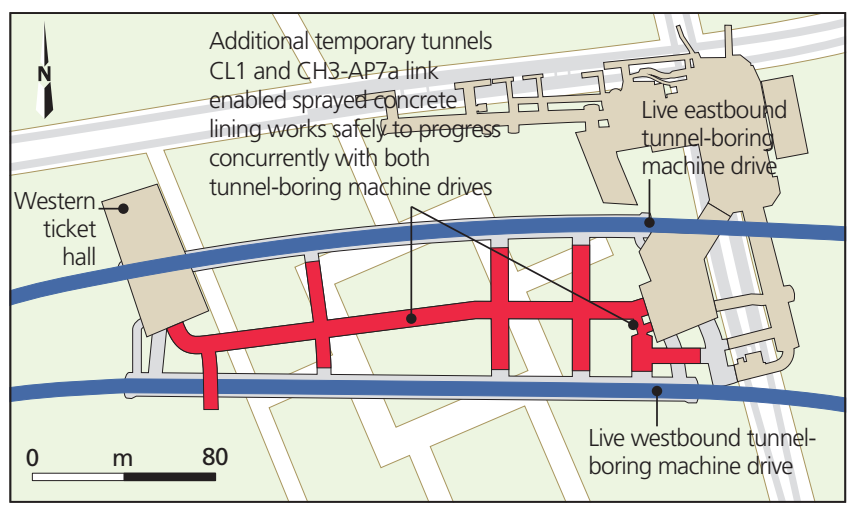

Figure 18. Tottenham Court Road station layout showing temporary tunnels (CL1 and AP7a/CH3 link) which enabled safe concurrent construction of both tunnel-boring machine drives and the sprayed concrete lining tunnels - a major cost and programme benefit

sprayed concrete lining tunnels to be constructed in parallel with the tunnel-boring machine drives. This provided the project with a dramatic reduction in programme risk, and savings of around 3 months and $£ 3$ million.

Details of the successful sprayed concrete lining works undertaken at Tottenham Court Road are documented elsewhere (Batty et al., 2016a, 2016b; Perkins et al., 2016; St. John et al., $2015 b)$. However, some particular aspects of these works serve as a useful reference for future projects.

The contractor designed and procured sufficient toolbox items (e.g. spiles, in-tunnel depressurisation, face dowels and pocket excavations) to cope safely with a wide array of potential ground 
Civil Engineering

Volume 170 Issue CE5
Crossrail project: a deep-mined station

on the Elizabeth line, London

St. John, Barker, Frost and Harris conditions. This was a responsible and diligent approach but, in the event, no spiling was deployed and no depressurisation was required. The face dowels were neither practicable nor necessary in the ground conditions encountered, namely very stiff, dry, London Clay (A2/A3 sub-units with claystone bands) with generally good clay cover both above and below the tunnels. Limited pocket excavations were deployed on only two advances to cope with locally reduced clay cover at ventilation tunnel VWW (Perkins et al., 2016). Low clay cover was encountered at one location (VWW), and both known and unknown obstructions were encountered within two other tunnels (tube à manchette in VEW, and an uncharted well in CH3 under Soho Square) (Perkins et al., 2016).

Having started in February 2013, the sprayed concrete lining works at Tottenham Court Road were completed by March 2015 and handed over to the fit-out contractor in a phased manner ahead of schedule, with an exemplary safety record. The station fit-out and the system-wide works will be the subject of further technical papers.

\section{Asset protection}

Undertaking such large-scale civil engineering and tunnelling works on Oxford Street and beneath Soho was never going to be a simple challenge, not least because of extremely small and restricted urban worksites and trying to be a 'good neighbour' to more than 3500 stakeholders including London Underground, listed buildings, churches, sensitive recording studios and the historic House of St Barnabas. Traffic and pedestrian control, and control of noise and vibration were also crucial to the safe operation of the site and public perception of the works.

Asset protection methods entailed the sinking of seven compensation grout shafts with extensive horizontal arrays of tube à manchettes to control ground settlement caused by tunnelling and box excavation. Four shafts were located in the corners of Soho Square, another south of Goslett Yard box, another in Sheraton Street and one in Dean Street immediately adjacent to the western ticket hall structure (see Figures 19 and 20).

From the outset, the most critical works involved the installation of more than 2700 manual and automated monitoring points on nearby buildings and assets, including seven robotic total stations and state-of-the-art hydraulic levelling cells, and integrating into this

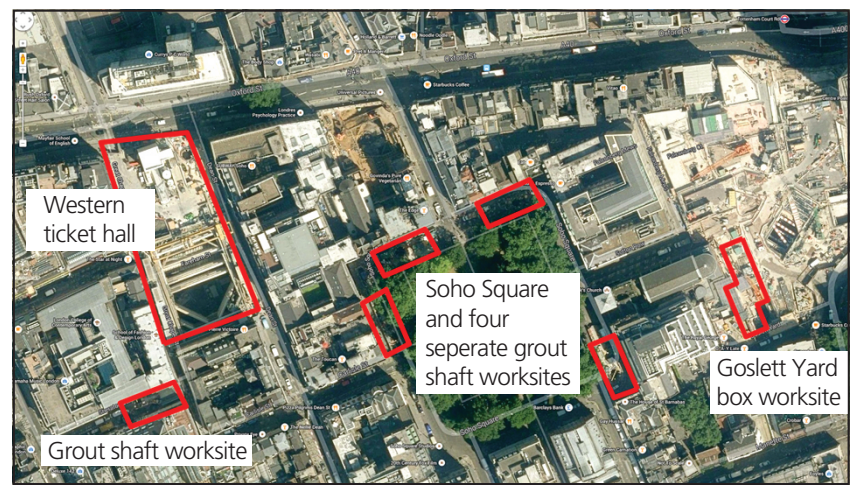

Figure 19. Tottenham Court Road station layout worksites (in red) around Dean Street, Oxford Street and Soho Square network the instrumentation and monitoring which had previously been installed by others. In parallel with this, major utilities diversions were undertaken within Soho Square to make space for four of the seven temporary shafts for compensation grouting.

Once the grout shafts had been sunk, approximately $22000 \mathrm{~m}$ of tube à manchettes up to $90 \mathrm{~m}$ long were drilled within the London Clay approximately $5 \mathrm{~m}$ above the crown of the new tunnels. The baselining of the instrumentation and monitoring, and the pretreatment of the tubes-à-manchette, provided the project with the required level of asset protection to permit large-scale excavation and tunnelling to commence. The establishment of real-time monitoring and the use of formal shift review group meetings were critical to the success of the project, enabling tunnelling works to progress safely and to protect nearby assets (Yu et al., 2015).

It is testament to the skill and professionalism of those involved with the monitoring and compensation grouting works that such complex tunnelling and mitigation works could be undertaken safely and largely unnoticed in such a sensitive area.

\section{Key lessons learned}

There are a number of lessons learned and critical success factors, some of which are not included in this paper for reasons of brevity, which may be of use to future projects.

- The 'tunnel-boring machine first' strategy was a key factor in the successful delivery of the works and delivered huge benefits (St. John et al., 2015b).

- When defining the limits of deviation, greater consideration should be given to ensure sufficient working space for temporary worksites. This approach will also offer greater flexibility and efficiency in the permanent works solutions.

- It is important to retain sufficient flexibility in the design, particularly if 'programme engineering' initiatives are required to re-work the design in response to key programme drivers (e.g. 'tunnel-boring machine first' initiative).

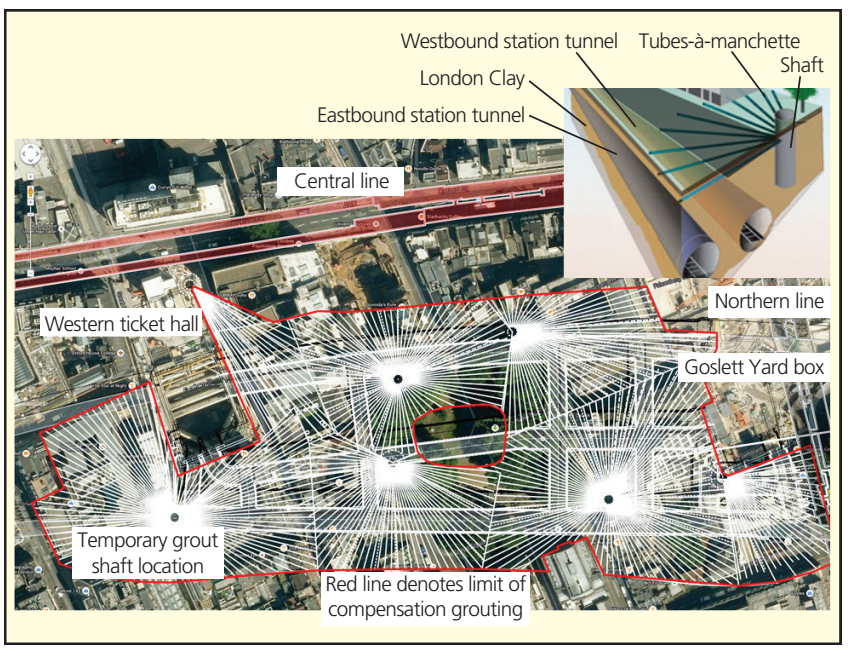

Figure 20. Tottenham Court Road station layout showing temporary grout shafts and the extent of compensation grouting (inset schematic diagram of compensation grouting arrangement) 
- A key strategic decision was made regarding the design of the sprayed concrete lining secondary linings. There are pros and cons to both the cast in situ (with sheet waterproofing) option and the sprayed secondary lining option (with sprayed waterproofing and sprayed fireproofing layer). For a detailed comparison between the methods, refer to published papers (Batty et al., 2016a, 2016b).

- In respect of ground conditions, the approach taken was the most responsible and diligent in the circumstances: plan for the worst and hope for the best, both in terms of the propping design and the sprayed concrete lining temporary measures.

- Control of ground movements was exemplary, due mainly to the collaboration and co-operation between the various parties. This required significant investment in extensive instrumentation and monitoring and compensation grouting to control and mitigate ground movement, with critical works reviewed and controlled by way of the daily review meetings and the required excavation support sheet.

- The dedicated on-site shotcrete batching plant proved to be a significant benefit for the project.

- Where possible, the permanent works configuration should allow for the running tunnels to pass next to (not through) the ticket hall box. If possible, a dedicated temporary access to the tunnels should be provided to permit concurrent construction of the ticket halls and the running tunnels. If this configuration is not possible then the ticket hall base slab should be constructed as early as possible to avoid blocking access through the tunnels at a later date.

- Having a connection between the eastern and western concourses offered considerable benefits during the construction process, unlocking both programme and logistical constraints.

- Proactive stakeholder management was a worthwhile investment. The overwhelming positive public impression of the project was achieved through hard work and dedicating considerable full-time resources.

\section{Conclusions}

Tottenham Court Road station on the new Elizabeth line has been successfully delivered safely, on time and on budget to the fit-out contractor. This paper has described some of the lessons learned and factors which proved critical to the overall success of the scheme.

Management and co-ordination of design and construction across numerous complex interfaces presented the most significant challenge. The scale and complexity of the works necessitated strong collaboration and effective technical and construction co-ordination to achieving a successful outcome. In the light of this, it is recommended that future external or cross-contract interfaces should be eliminated or reduced as much as possible; those interfaces that are left require careful and proactive management.

The contractual model deployed at these interfaces should create a shared stake in success or failure, with appropriate key performance indicators to engender behaviours that ensure the best possible overall outcome for the project.

\section{Acknowledgements}

The authors would like to thank the many individuals and companies who have supported the production of this paper. Particular thanks go to Jonathan Gold, Andy Pickett, Olivia Perkins and Graham Williams for their valuable contributions to this paper.

\section{References}

Batty E, Skarda A and Kentish E (2016a) Challenges of spraying a $50 \mathrm{~mm}$ thick fireproofing layer. Proceedings of the World Tunnel Congress 2016, ITA-AITES Proceedings, San Francisco, CA, USA.

Batty E, Skarda A, Kentish E, Webber S and Bond N (2016b) Comparison between in situ and sprayed secondary linings. Proceedings of the World Tunnel Congress 2016, ITA-AITES Proceedings, San Francisco, CA, USA.

BBC2 (2016) 'The Fifteen Billion Pound Railway' Featuring the 'Tunnelling through the Eye of the Needle'. See https://www.youtube.com/ watch?v=42-IJ2y6ddQ (accessed 16/07/2016)

de Silva M and Paris R (2015) Delivering Crossrail, UK: a holistic approach to sustainability. Proceedings of the Institution of Civil Engineers Engineering Sustainability 168(4): 151-158.

Gakis A, Salak P and St. John A (2015) Innovative geotechnical risk management for $\mathrm{SCL}$ tunnels. Proceedings of the Institution of Civil Engineers - Geotechnical Engineering 168(5): 385-395.

Li Y, Stephens J and Ryba A (2014) Four-dimensional modelling on Tottenham Court Road station, London, UK. Proceedings of the Institution of Civil Engineers - Civil Engineering 167(5): 33-40, http://dx. doi. org/10.1680/cien.13.00019.

Nicholson D, Tse CM and Penny C (1999) The Observational Method in Ground Engineering: Principles and Applications. Ciria, London, UK, R185.

Perkins O, St. John A, Potts V and Sismondi S (2016) Management of obstructions and adverse ground conditions during sprayed concrete lining tunnelling works at Bond Street and Tottenham Court Road stations for Crossrail contract C300/410. Proceedings of the World Tunnel Congress 2016. ITA-AITES Proceedings, San Francisco, CA, USA

Pickett A (2015) Crossrail sprayed concrete linings. In Crossrail Project: Infrastructure, Design and Construction (Black M, Dodge C and Lawrence U (eds)). Thomas Telford and Crossrail, London, UK, vol. 1, pp. 137-153.

St. John A, Pickett A, Kendall A, Potts V and McGirr D (2015a) Delivering a safe integrated sprayed concrete lining design: the challenges and successes of Crossrail Contract C300/C410. In Crossrail Project: Infrastructure, Design and Construction (Black M, Dodge C and Lawrence U (eds)). Thomas Telford and Crossrail, London, UK, vol. 1, pp. 331-348.

St. John A, Potts V, Perkins O and Balogh ZS (2015b) Use of tunnel boring machine pilot tunnels for large diameter sprayed concrete lining caverns, Crossrail C300/C410. In Proceedings of the World Tunnel Congress 2015 Promoting Tunnelling in South East European Region, Dubrovnik, Croatia. Hubitg and ITA Croatia, p. 734.

Su J and Thomas A (2015) Design of sprayed concrete linings in soft ground - a Crossrail perspective. In Crossrail Project: Infrastructure, Design and Construction (Black M, Dodge C and Lawrence U (eds)). Thomas Telford and Crossrail, London, UK, vol. 1, pp.123-136.

Yeow HC, Nicholson D, Man CL et al. (2014) Application of observational method at Crossrail Tottenham Court Road station. Proceedings of the Institution of Civil Engineers - Geotechnical Engineering 167(2):182193.

Yu J, Standing J, Vollum R, Potts D and Burland J (2015) Stress and strain monitoring at Tottenham Court Road Station, London, UK. Proceedings of the Institution of Civil Engineers - Structures and Buildings 168(2): 107-117. 